\title{
A Novel Beta Globin Gene Polymorphism in Turkish Population: IVS-II $706 \mathrm{G}>A$
}

\section{Beta Globin Geninde Türk Toplumunda Illk Kez Saptanan Bir Polimorfizm: IVS-II $706 \mathrm{G}>\mathrm{A}$}

\author{
Nejat Akar1, Serdar Ceylaner2, Haldun Doğan1 \\ 1 TOBB-Economy and Technology University Hospital, Clinic of Pediatrics, Ankara, Turkey \\ 2Intergen Genetic Diagnosis Research and Education Center, Ankara, Turkey
}

Key words: Polymorphism, thalassemia

Anahtar kelimeler: Polimorfizm, talasemi

Over 2000 mutations were reported at the beta globin gene including hemoglobin variants. These polymorphisms and mutations are important from the clinical and genetic counseling point of view (1).

Recently an unrelated couple was admitted our department for genetic counseling for beta thalassemia. The reason for the admission of the family was that they were said to be both beta thalassemia carriers in another center.

Analysis revealed that the father was a beta thalassemia carrier of the previously reported $\mathrm{Cd} 44$ delC mutation in heterozygous state. The mother was hematologically and electrophoretically normal. Neither carried the common alpha thalassemia mutations. She was pregnant for the proband (Table I). The family asked further investigation to be sure whether the mother was a beta thalassemia carrier or not.

HBB gene sequencing analysis was performed using the MiSeq next generation sequencing (NGS) platform (Illumina, San Diego, CA, USA) and ABI 3130 sequencer (USA). Genomic DNA of all the family members was extracted according to the manufacturer's standard procedure using the QIAamp DNA Blood Midi Kit (Qiagen, Hilden, Germany). The DNA samples were quantified with a NanoDrop 1000 (Thermo Fisher Scientific Inc. Waltham, MA USA) spectrophotometer and used at a concentration of $50 \mathrm{ng} /$ $\mu \mathrm{L}$. Promotor region, all exons and introns of the HBB gene were amplified using PCR primers. PCRs were validated by using agarose gel electrophoresis. PCRs for each individual were mixed to obtain PCR pools, purified and quantified. Purifications were done by using NucleoFast ${ }^{\circledR} 96$ PCR cleaning procedure (Macherey-Nagel $\mathrm{GmbH}$, Germany) and quantification of purified PCRs were done by using NanoDrop 1000. Quantified PCR pools were then standardized to 0.2 ng/ul. The libraries were prepared with the NexteraXT kit (Illumina Inc.), according to the manufacturer's instructions. Next-gene sequencing was carried on MiSeq (Illumina Inc.). Sequences were aligned to the hg19 genome within MiSeq Reporter software (Illumina Inc.). Visualization of the data was performed with IGV 2.3 (Broad Institute) software. A novel polymorphism at IVS-II 706 (G>A) was discovered (Figure 1).

Sequence analyses of 250 healthy individuals were done retrospectively. None of them had this polymorphism. Beta globin gene IVS-II 706 (G>A) alteration is a single nucleotide polymorphism according to mutation tester and human splicing finder. This polymorphism was not previously reported and cannot be found at beta globin gene database (1). 


\begin{tabular}{|c|c|c|c|c|c|c|c|c|c|}
\hline Father member & $\mathrm{Hb}$ & RBC & MCV & MCH & МСHC & RDW & Beta & Thal & Mutation \\
\hline Father & 12.3 & 6.6 & 61.4 & 18.6 & 30,3 & 17.3 & $\mathrm{Cd} 44$ & deIC IVS-II & $706(\mathrm{G}>\mathrm{A})$ \\
\hline Mother & 13.3 & 4.63 & 86.4 & 28.7 & 33.3 & 14.1 & IVS-II & delC/IVS-II & $\begin{array}{l}706(\mathrm{G}>\mathrm{A}) / / \mathrm{IVS}-\mathrm{II} \\
706(\mathrm{G}>\mathrm{A})\end{array}$ \\
\hline Child (6 months) & 9.9 & 5.45 & 53.0 & 18.2 & 34.3 & 23.6 & $\mathrm{Cd} 44$ & deIC/IVS-II & $706(G>A)$ \\
\hline Child (18 months) & 9.8 & 5.5 & 55.0 & 17.9 & 32.5 & 25.1 & $\mathrm{Cd} 44$ & deIC/IVS-II & $706(G>A)$ \\
\hline
\end{tabular}

U: Unremitting, WBC: white blood cell, ESR: erythrocyte sedimentation rate, ALT: Alanine aminotransferase, AST: Aspartate aminotransferase, LDH: Lactate dehydrogenase, MMDM: Modified megadose methylprednisolone, IVIG: intravenous immunoglobulin, CsA: Cyclosporine A

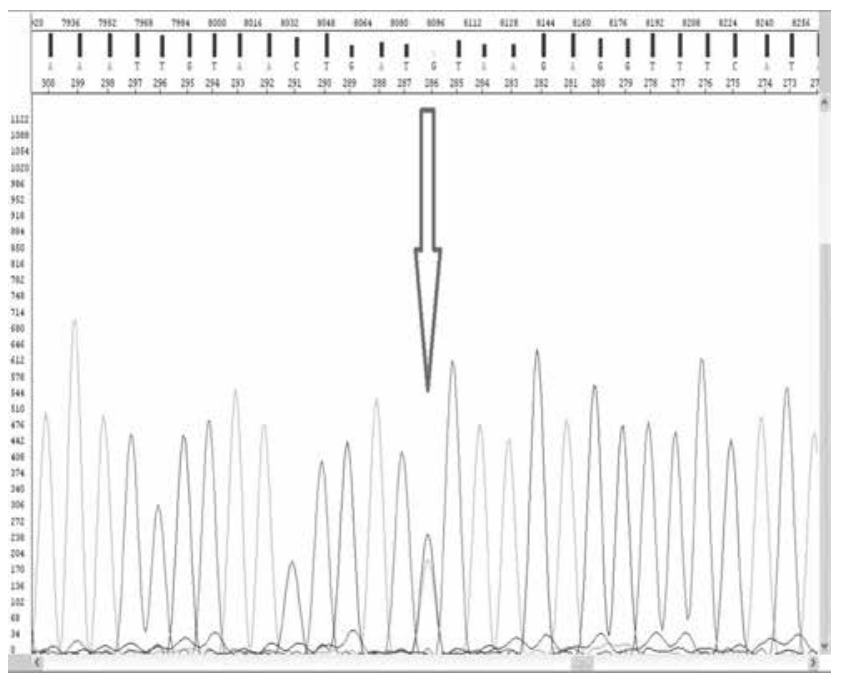

Figure 1. Sequencing data of the beta globin gene IVS-II $706(\mathrm{G}>\mathrm{A})$ polymorphism

The father and his son carries Cd44delC (c.135delC) (p.Phe45Leu fs*15) mutation in heterozygous state. Their whole blood count is similar to beta thalassemia carrier state. It is interesting that although the mother carried the IVS-II $706(\mathrm{G}>\mathrm{A})$ in homozygous state, she did not have anemia. Hematological and hemoglobin data of proband and his family members suggest that this novel IVS-II nt 706 (G>A) polymorphism does not alter maturation of pre- mRNA and does not have any effect on the hematological values. At this region of the gene several mutations associated with mild or severe b- thalassaemia have been described, such as IVS-II-654 (HBB: c.316-197 C>T), IVS-II-705 (HBB: c.316$146 \mathrm{~T}>\mathrm{G}$ ), IVS-I-726 (HBB: c.316-125 A>G) and IVS-II-745 (HBB: c.316-106 C>G) (20) IVS-II (HBB nt 478 C>A) (2,3). Furthermore, although the family claimed that they were not related, family histories of the father and mother linked them to two different villages established almost 170 years ago, 30 kilometers apart from each other at the Tokat region of Turkey.

In conclusion, in order to give a reliable, appropriate clinical and genetic counseling to the families, it is very important to report nucleotide changes found in any gene (mutation or polymorphism), either to a database or as an article. Moreover, it is worth taking the historical background of the families.

\section{References}

1. http://globin.bx.psu.edu

2. Orkin SH, Kazazian HH Jr, Antonarakis SE, et al. Linkage of beta-thalassaemia mutations and beta-globin gene polymorphisms with DNA polymorphisms in human betaglobin gene cluster. Nature 1982; 296:627-31.

3. Vinciguerra $M$, Passarello $C$, Leto $F$, et al. Identification of three new nucleotide substitutions in the $\beta$-globin gene: laboratoristic approach and impact on genetic counselling for beta-thalassaemia. Eur J Haematol 2014: 92;444-9. 